\title{
Comparison of four different training programs in body composition and strength in
}

\section{women over 55 years}

\author{
Comparação de quatro diferentes programas de treinamento na composição corporal e força em \\ mulheres com mais de 55 anos \\ Comparación de cuatro programas de entrenamiento diferentes sobre composición corporal y
} fuerza en mujeres mayores de 55 años

Received: 09/06/2021 | Reviewed: 09/13/2021 | Accept: 09/23/2021| Published: 09/24/2021

\author{
Anderson Leandro Peres Campos \\ ORCID: https://orcid.org/0000-0001-8503-7934 \\ Universidade Federal da Bahia, Brazil \\ E-mail: anderson@gruponobre.net \\ Lourenço dos Santos Del Ponte \\ ORCID: https://orcid.org/0000-0002-6156-9802 \\ Universidade Federal de Pelotas, Brazil \\ E-mail: 1delponte@hotmail.com \\ Matheus Cunha dos Santos Goes \\ ORCID: https://orcid.org/0000-0001-8427-4567 \\ Universidade Estadual de Feira de Santana, Brazil \\ E-mail: matheuscunhagoes@gmail.com \\ Mariângela da Rosa Afonso \\ ORCID: https://orcid.org/0000-0002-8853-719X \\ Universidade Federal de Pelotas, Brazil \\ E-mail: cafonso@terra.com.br \\ Marcelo Cozzensa da Silva \\ ORCID: https://orcid.org/0000-0003-2336-7131 \\ Universidade Federal de Pelotas, Brazil \\ E-mail: cozenssa@terra.com.br
}

\begin{abstract}
There is no doubt of the benefits brought by the practice of physical exercises in the promotion of health, but the use of combined capacities in a same session is still contradictory. The aim of the present study was to verify the influence of a 10- week program of concurrent training on body composition and strength in adult women comparing it to programs of strength and aerobic activities. Thirty women were selected with minimum age of 55 years, randomized in four groups: group $\mathrm{A}^{1}$ (aerobic activity following by strength training), group $\mathrm{F}^{1}$ (strength training followed by aerobic activity), group A (aerobic training), group F (strength training). The body fat showed differences among the groups, the group $\mathrm{F}$ was significantly lower than $\mathrm{A}$ and $\mathrm{A}^{1}$; when strength was analyzed the results demonstrated differences in the lumbar area in the group $\mathrm{A}^{1}$ and in the strength of inferior members in $\mathrm{A}, \mathrm{A}^{1}$ and $\mathrm{F}$ from pre- to post-test. Based on the data, we conclude that excepting of body composition, there is no variance in the analyzed variables in this group of women according to the type of training performed.
\end{abstract}

Keywords: Physical exercise; Aging; Concurrent training; Aerobic exercise; Resistance exercise.

\section{Resumo}

Não há dúvida dos benefícios trazidos pela prática de exercícios físicos na promoção da saúde, mas a utilização de capacidades combinadas em uma mesma sessão ainda é contraditória. O objetivo do presente estudo foi verificar a influência de um programa de 10 semanas de treinamento concorrente na composição corporal e nos níveis de força de mulheres adultas comparando-o a programas de força e atividades aeróbias. Foram selecionadas 30 mulheres com idade mínima de 55 anos, divididas aleatoriamente em quatro grupos: grupo $\mathrm{A}^{1}$ (atividade aeróbia seguida de treinamento de força), grupo $\mathrm{F}^{1}$ (treinamento de força seguido de atividade aeróbia), grupo A (treinamento aeróbio), grupo $\mathrm{F}$ (treinamento de força). O percentual de gordura apresentou diferença entre os grupos, sendo o grupo $\mathrm{F}$ significativamente menor que $\mathrm{A}$ e $\mathrm{A}^{1}$; quando analisada a variável força foram encontradas alterações na força da região lombar no grupo $\mathrm{A}^{1}$ e na força de membros inferiores em $\mathrm{A}, \mathrm{A}^{1}$ e $\mathrm{F}$ do pré- para o pós-teste. Baseado nos dados, conclui-se que, com exceção da composição corporal, não existe alteração das demais variáveis estudadas nesse grupo de mulheres de acordo com diferença do tipo de treinamento executado.

Palavras-chave: Treinamento concorrente; Envelhecimento; Exercício físico. 


\section{Resumen}

No cabe duda de los beneficios que aporta la práctica del ejercicio físico en la promoción de la salud, pero el uso de habilidades combinadas en una misma sesión sigue siendo contradictorio. El objetivo del presente estudio fue verificar la influencia de un programa de entrenamiento concurrente de 10 semanas sobre la composición corporal y los niveles de fuerza de mujeres adultas, comparándolo con programas de fuerza y actividad aeróbica. Se seleccionaron treinta mujeres con una edad mínima de 55 años, divididas aleatoriamente en cuatro grupos: grupo A1 (actividad aeróbica seguida de entrenamiento de fuerza), grupo F1 (entrenamiento de fuerza seguido de actividad aeróbica), grupo A (entrenamiento aeróbico), grupo $\mathrm{F}$ (entrenamiento de fuerza). El porcentaje de grasa mostró una diferencia entre los grupos, siendo el grupo F significativamente más bajo que el A y el A1; cuando se analizó la variable fuerza, se encontraron cambios en la fuerza de la región lumbar en el grupo A1 y en la fuerza de los miembros inferiores en A, A1 y F desde el pre-post-test. Con base en los datos, se concluye que, a excepción de la composición corporal, no existe cambio en el resto de variables estudiadas en este grupo de mujeres según la diferencia en el tipo de entrenamiento realizado.

Palabras clave: Entrenamiento competitive; Envejecimiento; Ejercicio físico.

\section{Introduction}

The human aging process is associated with sarcopenia, manifested by weakness and functional impairment, symptoms that appear at the age of 40 with a loss of strength rate of $1 \%$ per year, after the acceleration of each exercise (Doherty, 2003).

In general, physical exercise programs aimed at promoting health should be changed to develop and / or maintain body composition, aerobic capacity, muscle strength and endurance. However, it indicates that the quantity and quality needed to promote positive health effects may differ from those used to improve skills.

There is an agreement that the rate of decline in maximum oxygen volume (maximum VO2) is approximately $1 \%$ per year in sedentary men and, on average, as women have a lower maximum VO2 index with age. However, the loss of muscle strength is primarily responsible for the deterioration of mobility and the functional capacity of the aging individual. This process increases muscle mass, increases intramuscular fat and reduces the ability to generate strength.

Despite the high number of publications on strength training in the elderly, the model, frequency, volume and intensity of training to optimize muscle strength gain are still obscure (Brandon, 2000; Adams, 2001).

In the sedentary elderly, this becomes a major problem, as such changes are important for carrying out activities of daily living. Avoiding falls in situations of body imbalances is an important function of strength, a fundamental aspect for the physical integrity of the elderly. In women there seems to be losses in the maximum voluntary contraction and in the speed of contraction at the age of 40, while the speed of relaxation is decreased at the age of 50 (Paasuke, 2000).

However, there is no doubt about the benefits brought by physical exercise in promoting health, as well as the importance of using aerobic and strength exercises. But when it comes to strength, some authors suggest that concurrent training may hinder its development (Bell, 2000; Hennessy, 1994).

However, the same does not seem to occur when concurrent training is evaluated on the effects of aerobic capacity, and may even improve its results (Mccarthy, 2002; Pollock, 2000). Concurrent training, demonstrated that it resulted in an attenuation of type I muscle fiber hypertrophy when compared to isolated strength training, possibly due to different neural adaptations (Kraemer, 1995; Leveritt, 1999; Putman, 2004). Others state that concurrent training can simultaneously improve the strength and endurance of untrained subjects, when the training volume and the duration of the period are not very prolonged (Hakkinen, 2003; Mccarthy, 2000; Viana,2007). In this sense, the objective of the present study was to verify the influence of a 10-week concurrent training program on parameters, strength and body composition of adult women compared to the responses of strength programs and aerobic activities alone. 


\section{Methodology}

The study was carried out on the premises of the School of Physical Education (ESEF) of the Federal University of Pelotas (UFPel). Thirty female individuals with a minimum age of 55 years were selected, randomly divided into four groups: group $\mathrm{A}^{1}$ (aerobic activity followed by weight training), group $\mathrm{F}^{1}$ (strength training followed by aerobic activity), group $\mathrm{A}$ (aerobic training only), group F (strength training only). The exclusion criteria were considered: being a smoker, having performed any type of physical exercise in the last three months, presenting any disease that prevented the regular practice of physical exercises proven by presenting a medical certificate. Classes were held in the afternoon, with an interval between sessions of at least 48 hours for recovery. Both groups were instructed to maintain their activities of daily living (ADLs) and not to perform any type of physical exercise during the period of the experimental protocol.

The program ran for 10 consecutive weeks, comprising three weekly sessions lasting one hour and ten minutes for groups $\mathrm{A}^{1}$ and $\mathrm{F}^{1}$ and forty minutes for groups $\mathrm{A}$ and $\mathrm{F}$, where the first and final five minutes were used for warm-up and it returns to calm for all groups, and a maximum limit of three absences has been established for the permanence in the program. Group $\mathrm{A}^{1}$ performed 30 minutes of aerobic exercise on a cycle ergometer and, shortly thereafter, a weight training series consisting of eight exercises involving large and small groups muscle: seated bench press, pulled from behind, knee extension, knee flexion, biceps pulley, triceps pulley, plantar and abdominal flexion on the floor. The $\mathrm{F}^{1}$ group performed the same activities as the $\mathrm{A}^{1}$ group, only with their inverted order (strength training followed by aerobic exercise). Group $\mathrm{F}$ performed only strength training (eight exercises) and group A only aerobic exercise (30 minutes). All experimental treatments were carried out simultaneously in the same place. For a better understanding of the participants as to the order in which the activities were carried out, cards of different colors were adopted for each group.

\section{Evaluation Protocol}

At the beginning of the research, all components of the sample were invited to visit the Laboratory of Biochemistry and Exercise Physiology at ESEF / UFPel, where the baseline tests were carried out. For the measurement of body mass, a Filizola digital scale was used with an accuracy of $0.01 \mathrm{~kg}$, height with a $200 \mathrm{~cm}$ Sanny stadiometer. The strength of the lower limbs and lumbar was measured using dynamometry in a dynamometer from the Baseline brand (United States) with a precision of $10 \mathrm{Kgf}$ and the handgrip strength using a dynamometer from the Jamar brand (Canada) with a precision of $2 \mathrm{Kgf}$. The percentage of fat was determined by measuring the circumferences according to the equation proposed by Tran $\&$ Weltmann (1989) ${ }^{23}$ for women up to 78 years old with inelastic metallic tape from the Sanny brand. Skin folds, tricipital, bicipital, subscapular, suprailiac, abdominal, medial thigh and medial leg, were collected in order to obtain a sum and estimate of the effects of exercises on body fat parameters. For this purpose, a Harpenden Scientific plicometer of the Cescorf brand (Brazil) with $0.1 \mathrm{~mm}$ precision was used.

The weight training load was determined using the 10 RM repetition test.

\section{Exercise prescription}

After the end of the evaluations, an adaptation period of two weeks was carried out to better assimilate the participants to the order and performance of the exercises. Soon after, the program began, where classes were one hour and ten minutes long with the first and final five minutes destined, respectively, to warm up and return to calm. The remaining time was divided equally between aerobic and strength training. The weight training used loads equivalent to $70 \%$ of the load test throughout the program, where 3 sets of 8 repetitions were performed for each exercise, except abdominal exercises $(3$ sets of 30 repetitions). The intervals between exercises that made up the weight training series lasted approximately 60 seconds. The activities were performed in pairs, so that while one performs the exercise the other rests. For the prescription of aerobic 
activity, the Borg Perceived Effort Scale between 13 and $15 .{ }^{3}$ was used. At the end of the 10 weeks of study, the individuals were reevaluated.

The research was approved by the Research Ethics Committee of the Faculty of Physical Education of the Federal University of Pelotas on protocol number 051/2009.

\section{Statistical analysis}

Data analysis was performed using descriptive statistics (mean $\pm \mathrm{SD}$ ) and inferential statistics (ANOVA one way). The normality of the outcomes was tested, in order to meet the assumptions of inferential statistics. For the variables used as an outcome that presented an asymmetric distribution, nonparametric tests were used in the analysis. Statistical significance $p$ $<0.05$ was accepted and the statistical package used for data analysis was Stata 9.0.

\section{Results and Discussion}

Thirty elderly female subjects were analyzed ( 6 in group $\mathrm{A}^{1}, 3$ in group $\mathrm{F}^{1}, 11$ in group $\mathrm{A}$ and 10 in group $\mathrm{F}$ ), all over the age of 55 years, as shown in Table 1. The results of the analysis of body composition, Fat $\%$, WHR and $\sum$ folds, are presented as mean and standard deviation (Table 2). The degree of lumbar strength, lower limbs and handgrip (table 3) are also presented as mean and standard deviation.

Table 1: Characterization of the sample at the beginning of the study with women over 55 years old (mean \pm SD).

\begin{tabular}{lllll}
\hline Group & Weight Kg & Stature & IMC & Age \\
\hline AF & $80,2 \pm 7,8$ & $157 \pm 6$ & $31,6 \pm 3,3$ & $60 \pm 5$ \\
FA & $70,5 \pm 13$ & $161 \pm 6$ & $30,9 \pm 5,8$ & $60 \pm 5$ \\
A & $68,7 \pm 10,7$ & $157 \pm 6$ & $29,5 \pm 4,2$ & $63 \pm 5$ \\
F & $68,6 \pm 7,4$ & $160 \pm 5$ & $26,5 \pm 3,8$ & $60 \pm 3$ \\
\hline
\end{tabular}

Source: Authors.

Table 2: Comparison of pre- and post-test body composition averages by group and between groups.

\begin{tabular}{|c|c|c|c|c|c|c|}
\hline \multirow[t]{2}{*}{ Group } & \multicolumn{2}{|l|}{$\%$ Fat } & \multicolumn{2}{|l|}{ RCQ } & \multicolumn{2}{|l|}{$\sum$ Folds } \\
\hline & Before & After & Before & After & Before & After \\
\hline $\mathrm{AF}$ & $44 \pm 1$ & $45 \pm 2^{\#}$ & $86,9 \pm 0,6$ & $87,2 \pm 0,5$ & $189,9 \pm 39$ & $167,8 \pm 19$ \\
\hline FA & $44 \pm 7$ & $44 \pm 7$ & $85,0 \pm 0,3$ & $86,0 \pm 0,3$ & $186,9 \pm 58$ & $162,0 \pm 52$ \\
\hline A & $44 \pm 3$ & $44 \pm 4^{\#}$ & $86,6 \pm 0,6$ & $87,1 \pm 0,6$ & $208,3 \pm 16$ & $187,7 \pm 19$ \\
\hline $\mathrm{F}$ & $39 \pm 5$ & $36 \pm 7^{\#}$ & $81,5 \pm 0,9$ & $82,0 \pm 0,7$ & $161,8 \pm 44$ & $145,6 \pm 32$ \\
\hline
\end{tabular}

\# Post-test difference between groups $\mathrm{p}=0.04$. Source: Authors. 
Table 3: Means and standard deviation of the dependent variable's lower limb strength, lumbar strength, handgrip strength, from pre to post-test by group and between groups.

\begin{tabular}{|c|c|c|c|c|c|c|}
\hline \multirow{2}{*}{$\begin{array}{l}\text { Group } \\
\mathrm{AF}\end{array}$} & \multicolumn{2}{|c|}{ Lumbar Dynamometry } & \multicolumn{2}{|c|}{ Lower limb dynamometry } & \multicolumn{2}{|c|}{ Hand Grip } \\
\hline & $52,8 \pm 10$ & $71,2 \pm 12^{\# \#}$ & $60,3 \pm 20$ & $91,7 \pm 21 \dagger$ & $29,5 \pm 3$ & $32,3 \pm 3^{\#}$ \\
\hline FA & $49,3 \pm 8$ & $63,3 \pm 11$ & $53,0 \pm 7$ & $81,7 \pm 17$ & $36,7 \pm 3$ & $31,7 \pm 7$ \\
\hline A & $55,4 \pm 14$ & $65,3 \pm 13 *$ & $54,9 \pm 13$ & $71,3 \pm 16^{* *}$ & $31,7 \pm 6$ & $30,2 \pm 6$ \\
\hline $\mathrm{F}$ & $55,8 \pm 11$ & $69,0 \pm 20$ & $53,5 \pm 7$ & $67,5 \pm 19$ \# & $30,7 \pm 2$ & $29,3 \pm 5$ \\
\hline
\end{tabular}

$* * * \dagger \# \# \#$ Difference from pre to post-test in the same group. ${ }^{*} \mathrm{P}=0.00 ; * * \mathrm{p}=0.01 ; \uparrow \mathrm{p}=0.02 ; \# \mathrm{p}=0.05$; \# \# $\mathrm{p}=0.03$. Source: Authors.

Table 4: Means and standard deviation of the variables Glycemia, Triglycerides and Total blood cholesterol, from pre to posttest by group and between groups.

\begin{tabular}{|c|c|c|c|c|c|c|}
\hline \multicolumn{2}{|c|}{ Pre treatment } & \multicolumn{5}{|c|}{ After treatment } \\
\hline & GLI (mg/dl) & TRI (mg/dl) & $\mathrm{COL}(\mathrm{mg} / \mathrm{dl})$ & GLI (mg/l) & TRI (mg/dl) & $\mathrm{COL}(\mathrm{mg} / \mathrm{dl})$ \\
\hline A & $110,36 \pm 23,0$ & $236,00 \pm 101,4$ & $234,27 \pm 22,3$ & $105,81 \pm 187$ & $185,72 \pm 72 *$ & $228,54 \pm 34,8$ \\
\hline $\mathrm{F}$ & $108,00 \pm 17,8$ & $160,09 \pm 93,4$ & $212,63 \pm 38,8$ & $103,36 \pm 18,3$ & $155,36 \pm 72,8$ & $203,18 \pm 42,8$ \\
\hline $\mathrm{AF}$ & $110,62 \pm 15,1$ & $195,87 \pm 81,0$ & $227,00 \pm 35,4$ & $97,62 \pm 9,6 \#$ & $197,87 \pm 99,6$ & $209,87 \pm 37,1$ \\
\hline FA & $102,63 \pm 18,7$ & $201,66 \pm 96,9$ & $221,66 \pm 40,5$ & $97,66 \pm 1,0$ & $299,33 \pm 90,1$ & $205,66 \pm 6,6$ \\
\hline
\end{tabular}

$* \mathrm{P}=0.002 ; \# \mathrm{P}=0.009 ;$ difference from pre to post test in the same group. Source: Authors.

After ten weeks of intervention, in the body composition variables, Table 2 shows significant results only in the posttests between the groups for the percentage of fat, where F was less than A1e A ( $\mathrm{p}=0.04)$. Regarding muscle strength, Table 3 shows results in the pre and post-test in the same group, where $A^{1}(p=0.05)$ for handgrip strength and $(p=0.02)$ for lower limb strength and $(\mathrm{p}=0.03)$ for lumbar dynamometry. Group A showed differences in lower limbs $(\mathrm{p}=0.01)$ and $(\mathrm{p}=0.00)$ for lumbar dynamometry, and F for lower limbs $(\mathrm{p}=0.05)$

The study of the effects of two or more physical capacities in the same training session is recent within the scientific scenario. Hickson (1980), was one of the pioneers in the study of concurrent training. In their study, individuals were randomly divided into three groups: aerobic (GA), strength (GF) and strength and aerobic (GFA), where GA performed activity six times a week for 40 minutes, GF five times a week for 30 minutes. / 40 minutes and GFE respected the same activity patterns as the other groups. After 10 weeks, the author concluded that simultaneous strength and endurance training reduced the ability to develop strength.

In the present study, changes were found in the strength levels of the lumbar region in group $\mathrm{A}^{1}$ and in the strength of lower limbs in $\mathrm{A}, \mathrm{A}^{1}$ and $\mathrm{F}$. Despite this, there was no difference in the gains in strength levels between the groups after 10 weeks. These results contradict the findings by Souza et al. (2007), which showed that aerobic exercises prior to strength exercises are not able to change the strength indices in the lumbar region. However, most studies that seek to verify the 
influence of the aerobic component on strength demonstrate that there is a loss in the degree of strength of lower limbs (Sporer, 2003). The improvement in the strength of the lower limbs, in groups $A$ and $A^{1}$, may be related, in addition to the work performed on bodybuilding by $\mathrm{A}^{1}$, with aerobic work on a cycle ergometer. A study by Macaluso et al. (2003), with elderly women over 65 years old, showed that a training program carried out on a cycle ergometer, regardless of pedaling speed, brought improvements in the increase in power and strength of these women's lower limbs.

Regarding the results of the fat percentage variable, the present study disagrees with the findings by Viana et al. (2007) which showed that there were no significant differences in the fat component in adult men when compared to concurrent training with strength or aerobic training, separately. Our study also found similar results by Rossato et al. (2007) who, with adult women, concluded that the performance of combined strength and endurance training, in the same session, is not capable of leading to significant changes in the body composition of these women. Sillanpaa et al. (2008), analyzed the adaptations of body composition, by DEXA, skinfolds, bioimpedance and waist circumference of 53 men between 40 and 65 years old during 21 weeks of concurrent training. The researcher observed that the fat percentage decreased, on average, from 5 to $8 \%$ similarly in all groups, concluding that the concurrent training (strength and endurance) was more efficient to decrease the fat percentage when compared to the isolated training. Our findings were also in agreement with Dolezal and Potteiger, (1998), who in their study, which lasted 10 weeks, found differences in the percentage of fat in the three groups analyzed: strength, aerobic and competitor.

Takeshima et al. (2004) studied the effect of concurrent training on healthy elderly, aged 60 to 83 years for 12 weeks with three weekly sessions to assess aerobic capacity, strength, flexibility and body composition. The training was carried out in the form of a 50-minute circuit, divided into two groups: intervention and control. The sample did not show differences in the sum of skinfolds, circumferences or biochemical profile.

Cadore et al. (2010), investigated the effect of CT, TF and TA on neuromuscular and hormonal parameters in elderly men. The training was carried out for 12 weeks with three weekly sessions. The individuals were evaluated for hormonal and strength parameters. There was a significant increase in strength in the lower limbs in all groups $(\mathrm{P}<0.05)$, with greater increases in strength $(67 \%)$ in TF $(41 \%)$ and both were superior to those in TA $(25 \%)(\mathrm{P}<0.01)$. Only TA and CT increased the strength of the lower limbs ( $\mathrm{P}<0.01)$, but with no significant difference between the two groups. however, significant increases in isometric strength and maximum muscle activation $(\mathrm{P}<0.05)$, as well as decrease in submaximal muscle activation for the same load that was only observed in $\mathrm{TF}(\mathrm{P}<0.05)$. The results suggest that the effect of the observed interference due to concurrent strength and resistance training may be related to the impairment of neural adaptations.

Maiorana et al. (2000), applied CT in elderly people with heart failure divided into two groups: CG and CT, for 8 weeks with three weekly sessions, where aerobic exercises were initially performed at $70 \%$ of HRmax and $85 \%$ from the sixth training week, and in strength training the intensity corresponded to $55 \%$ of $1 \mathrm{RM}$ and after the fourth week it increased to $65 \%$. The authors concluded that the CT was able to improve the aerobic capacity of the participants. A limitation of the study was the use of only one intervention group, thus making it impossible to compare training models.

Corroborating with the data found, the study by Campos et al. (2013), demonstrates that among active elderly women who performed concurrent training for 12 weeks and regardless of the order of execution, they presented better results, however, with no statistical difference to the control group. When comparing concurrent training with aerobic or strength training done in isolation, the results also point out that there is no difference between them. In another Da Silva (2010), study, in addition to agreeing with the statements of the study, he points out that the factor of increased strength is already a relevant point to be considered since it directly impacts the quality of life and daily activities of the elderly. 
Some limitations of the study need to be described. The methodological rigor for keeping women in the program meant that we had many losses, especially in the competing groups $\mathrm{A}^{1}$ (8 losses) and $\mathrm{F}^{1}$ (8 losses), which considerably reduced the power of the study. In addition, the participants' lack of food control may have influenced research results.

\section{Conclusion}

The present study concluded that in body composition, only the percentage of fat showed differences between the groups, where group $\mathrm{F}$ was significantly lower than $\mathrm{A}$ and $\mathrm{A}^{1}$. In relation to strength, group $\mathrm{A}^{1}$ showed improvement in the variable's lower limb strength and lumbar strength and groups A and F only in lower limb strength. Although there is no improvement in the results of the other variables, it is important to consider that none of them also presented negative results. This fact should be a positive factor, as, over time, these women tend to lose their physical capacities, which may make it difficult to perform activities of daily living and, consequently, worsen their quality of life.

It is suggested that further studies be carried out with the use of a longer intervention time and a larger sample of elderly women in order to obtain more accurate information about this type of training, which is still little researched in women in this age group.

\section{References}

Adams, K. J., Swank, A. M., Berning, J. M., Sevene- Adams, P. G., Barnard, K. L., \& Shimp-Bowerman (2001). Progressive strength training in sedentary, older African women. Med Sci Sports Exerc 33:1567-1576.

Bell, G. J., Syrotuik, D., Martin, T. P., Burnham, R., \& Quinney, H. (2000). Effect of strength training and endurance training on skeletal muscle properties and hormone concentrations in humans. Eur J Appl Physiol 81:418-427.

Borg, G. (1982). Psychophysical basis of perceived exertion. Med Sci Sports Exerc 14:377-381.

Brandon, J., Boyette, L., Gaasch, D., \& Lloyd, A. (2000). Effects of lower extremity training on functional mobility in older adults. J Aging Phys Activ 8:214227.

Campos, A. L. P., Del Ponte, L. S., Cavalli, A. S., Afonso, M. R., Schild, J. F. G., \& Reichert, F. F. Effects of concurrent training on health aspects of elderly women. Rev Bras Cineantropom Desemp Hum. 2013; 15(4):437-47.

Da Silva, M. C., Rombaldi, A. J., \& Campos, A. L. P. Ordem dos exercícios aeróbios e de força na aptidão física de mulheres acima de 50 anos. Rev Bras Cineantropom Desempenho Hum 2010;12(2):134-39.

Doherty, T. J. (2003). Invited review Aging and sarcopenia. J Appl Physiol 95:1717-1727.

Dolenza, B., \& Potteiger, J. (1998). Concurrent resistance and endurance training influence basal metabolic rate in nondieting individuals. J Appl Physiol 85: 695-700.

Gutteridge, J. M., \& Halliwell, B. (2000). Free radicals and antioxidants in the year:A historical look to the future. Ann Acad Sci 899:136:147.

Hakkinen, K., Alen, M., \& Kraemer, W. J. (2003). Neuromuscular Adaptations during concurrent strength and endurance training versus strength training. Eur J Appl Physiol 89: 42-52.

Hennessy, L. C., \& Watson, A. W. S. (1994). The interference effect of training for strength and endurance simultaneously. J Strenght Cond Res 8:12-19.

Hickson, R. C. (1980). Interference of Strength Development by Simultaneously Training for Strength and Endurance. Eur J Appl Physiol 45: 255-263.

Kraemer, W. J., Patton, J. F., \& Gordon, S. E. (1995). Compatibility of high intensity strength and endurance trainingon hormonal and skeletal muscle adaptations. J Appl Physiol 78:976-989.

Leveritt, M., Abernethy, P. J., Barry, B. K., \& Logan, P. A. (1999). Concurrent strength and endurance training: a review. Sports Med 28:413-427.

Macaluso, A., Young, A., Gibb, K. S., Rowe, D. A., \& De Vito, G. (2003). Cycling as a novel approach to resistance training increases muscle strength, power, and selected functional abilities in healthy older women. J Appl Physiol 95:2544-2553.

McCarthy, J. P., Pozniak, M. A., \& Agre, J. C. (2002). Neuromuscular adaptations to concurrent strength and endurance training. Med Sci Sports Exerc 34:511- 519 .

Paasuke, M., Ereline, J., Capeyeva, H., Sirkel, S., \& Sander, P. (2000). Age-related differences in twich contractile properties of plantarflexor muscles in women. Acta Physiol Scan 170:51-57. 
Research, Society and Development, v. 10, n. 12, e390101220268, 2021

(CC BY 4.0) | ISSN 2525-3409 | DOI: http://dx.doi.org/10.33448/rsd-v10i12.20268

Pollock, M. L., Franklin, B. A., Balady, G. J., Chaitman, B. L., Fleg, J. L., \& Fletcheb, B. (2000). AHA Science Advisory. Resistance exercise in individuals with and without cardiovascular disease: benefits, rationale, safety, and prescription: An advisory from the Committee on Exercise, Rehabilitation, and Prevention, Council on Clinical Cardiology, American Heart Association; Position paper endorsed by the American College of Sports Med Circulation $22: 828-833$

Putman, C. T., Xu, X., Gillies, E., Maclean, I. M., \& Bell, L. G. J. (2004). Effects of strength, endurance and combined training on myosin heavy chain content and fiber type distribution in humans. Eur J Appl Physiol 92:376-384.

Rossato, M., Binotto, M. A., Roth, M. A., Temp, H., Carpes, F. P., \& Alonso, J. L. (2007). Efeito de um treinamento combinado de força e endurance sobre componentes corporais de mulheres na fase de perimenopausa. Rev Port Cienc Desp 7: 92-99.

Sillanpaa, E., Hakkinen, A. Nyman, K, M., Cheng, S., Karavirta, L., Laaksonen, D., Huuhka, N., Kraemer, W. J., \& Hakkinen, K. (2008). Body composition and fitness during strength and/or endurance training in older men. Med Sci Sports Exerc 40: 950-958.

Souza, E. O., Tricoli, V., Franchini, E., Paulo, A. C., Regazzini, M., \& Ugrinowitsch, C. (2007). Acute effect of two aerobic exercise modes on maximum strength endurance. J Strenght Cond Res 21:1286-1290.

Sporer, B., \& Wenger, H. (2003). Effects of aerobic exercise on strength performance following various periods of recovery. J Strenght Cond Res 17:188-192.

Takeshima, N., Rogers, E., Islan, M., Yamaushi, T., Eiji, W., \& Okada, A. (2004). Effect of concurrent aerobic and resistance circuit exercise training on fitness in older adults. European Journal Applied Physiology. 93: 173-182.

Tran, Z. W., \& Weltmann, A. (1989). Generalized equations for predicting body density of women from girth measurements. Med Sci Sports Exerc 21:101104.

Viana, M. V., Filho, J. F., Dantas, E. H. M., \& Perez, A. J. (2007). Efeitos de um programa de exercícios físicos concorrentes sobre a massa muscular, a potência aeróbica e a composição corporal em adultos aeróbicos e anaeróbicos. Fit Perf J 6:136-142.

Wood, R. H., Reyes, R., Welsch, M. A., Manning, S. C., Matthew, L., Jonson, L. G., \& Hooper, P. F. (2001). Concurrent Cardiovascular and resistance training in healthy older adults. Med Sci Sports Exerc 33:1751-1758. 